\title{
Leder
}

\section{Profesjonsetiske utfordringer}

\author{
Berge Solberg, Rune Nydal \& Bjorn Myskja
}

Dette nummeret av Etikk i praksis er i utgangspunktet ikke et temanummer. Profesjonsetiske utfordringer synes likevel å utgjøre et gjennomgangstema $i$ de fleste av artiklene som utgis i dette nummeret. Det er en påminnelse om at en aldri blir ferdig med etiske problemstillinger innenfor et fagfelt, siden fagfeltene og profesjonelle oppgaver samt forventninger til profesjonen forandres hele tiden.

\section{Temanummer og «open access》}

Vi har siden tidsskriftet startet, valgt å satse på en serie med temanumre. Vi har invitert bidrag innenfor bestemte temaområder både for å sette fokus på aktuelle problemstillinger og for å løfte fram mangfoldet i anvendt etikk. Vi har hatt temanumre om teknologier for tilvalg og fravalg av barn, om nanoetikk og ELSA-studier, om religionens plass i det sekulære samfunnet, om spenningen mellom bredde- og eliteidealer i idretten, om kriser i moderne samfunn, om mobiltelefoner og moderne kommunikasjonsmedier og om bedriftenes samfunnsansvar $i$ et nordisk perspektiv. Gjennom denne bredden har vi markert at vi ønsker bidrag fra et bredt spekter av temaområder. Vi vil fortsette å ha tematiske numre, men vi skal alltid ha rom for artikler som ikke tematisk passer inn i det aktuelle temanummeret.

Tidsskriftets tilgjengelighet er avgjørende viktig ettersom vi har som målsetting at det skal være aktuelt for et bredt publikum. Vi er derfor svært tilfreds med at vi har blitt et «open access»-tidsskrift, noe vi også håper vil bidra til ytterligere å øke interessen for å publisere i tidsskriftet. 


\section{Bidrag i dette nummeret}

Tre av artiklene i dette nummeret har en medisinsk forankring. Morten Magelssen og Torbjørn Folstad spør om leger bør ha reservasjonsrett ved assistert befruktning. Bakgrunnen er endringen av bioteknologiloven i 2009 som muliggjorde at lesbiske par fikk tilgang til assistert befruktning innenfor det norske, offentlige helsevesenet. Lovendringen viste seg å være kontroversiell og avstedkom en fornyet debatt mellom leger om reservasjonsrett $\mathrm{i}$ legeyrket. Kan reservasjonsretten for leger forsvares, eller bryter den med legens plikt til å behandle pasienter uavhengig av deres tro, livsstil, seksuell legning, osv.? I hvilke saker og situasjoner er det eventuelt mulig å forsvare en reservasjonsrett? Disse spørsmålene har interessert Legeforeningens etiske råd i Norge de senere årene, ikke minst fordi nye kontroversielle tilbud har oppstått i det norske helsevesenet, som assistert befruktning for lesbiske og rituell omskjæring av guttebarn. Magelssen og Folstad mener det finnes tungtveiende grunner for en reservasjonsrett for leger, men bare i helt spesielle situasjoner og under helt spesielle vilkår. Artikkelen gir en oversikt over hvilke vilkår forfatterne sier må oppfylles for at en reservasjonsrett kan forsvares, og for at reservasjon skal kunne være forenlig med legers profesjonsetikk.

I artikkelen «Mellom samfunnsstrukturer og profesjon: om avgrensning, kultivering og premisser for adekvat skjønnsutøvelse i legerollen» stiller Kristine Bærøe spørsmålet om legene bør kunne sies å være seg selv nok i skjønnsutøvelsen i legerollen. Bærøe utdyper ulike former for skjønn i legerollen. Spesielt opptatt er hun av det hun kaller det distributive skjønnet - skjønnsutøvelse med tanke på hvem som skal få hva og når. Mye tyder nemlig på at legene utøver dette skjønnet høyst forskjellig, ut fra ulike normgrunnlag. Sånn sett kan legene neppe sies å være seg selv nok. Men i stedet for å foreslå å innskrenke legers mulighet for skjønnsutøvelse for å oppnå mer likebehandling av pasienter, retter Bærøe fokuset mot mulighetene som ligger i kultiveringen av legers skjønn. Artikkelen skriver seg inn $i$ en debatt om legers behov for etisk refleksjon, men Bærøe er tydelig på at kultivering av skjønn primært skjer gjennom erfaringsbasert refleksjon.

I «PGD-ens paradokser» gjennomgår Bjørn Hofmann den korte, men dog så omdiskuterte historikken rundt preimplantasjonsdiagnostikk (PGD) i Norge. PGD, som for alvor ble satt på dagsordenen med Mehmetsaken, tilbys i Norge i dag som en behandling i utlandet med godkjennelse av ei egen PGD-nemnd. Ved bruk av assistert befruktning og PGD kan risikopar for alvorlig arvelig sykdom få friske barn. I tillegg kan kvinner som av genetiske årsaker har problemer med å gjennomføre et svangerskap, øke sjansene for å klare å gjennomføre en vellykket graviditet gjennom spesifikk utvelgelse av befruktede egg. Endelig kan assistert befruktning, PGD og vevstyping benyttes til å lage såkalte «redningssøsken» som gir mulighet for å kurere eksisterende barn med alvorlig sykdom. Reguleringen av PGD, de 
etiske hensynene involvert og praksisen selv rommer en serie av paradokser. Det er disse paradoksene Hofmann tar tak i, i den hensikt å gjøre oss bedre i stand til å forstå debattene rundt PGD. Det er i dag en politisk diskusjon om PGD-nemnda er nødvendig for å ivareta etiske hensyn ved denne praksisen. Alternativet er at profesjonens egne medlemmer håndterer praksisen. Hofmann sitter selv i dagens nemnd. Om artikkelen gir svar på dette spørsmålet, skal vi ikke si noe om her.

Knut H. Sørensen og Lucía Liste Muñoz diskuterer en mulig skjev regional fordeling av kommunale tjenester som følger av utviklingen innenfor informasjons- og kommunikasjonsteknologi. I deres artikkel «Norske kommuner i elektronisk utakt? Fra sosiale til geografiske digitale ulikheter» presenterer de en innholdsrettet undersøkelse av alle Norges kommunale hjemmesider. Ettersom kvaliteten på kommunale hjemmesider varierer fra sted til sted, vil også informasjon om og tilgjengeligheten av kommunale tilbud og tjenester variere fra sted til sted. Denne sosiale skjevfordelingen av offentlige goder, som dette i praksis vil innebære, er forårsaket av overgangen til en digital formidling av informasjon og tjenester. De kommunalt ansattes forpliktelse til å gi likt tilbud til alle er her utfordret av de nye digitale redskapene. Denne skjevfordelingen er imidlertid regional og ikke, slik den etiske diskusjonen om digitale ulikheter ofte er satt, et spørsmål om brukeres kompetanse eller tilgjengelighet til datamaskiner.

I artikkelen «Den etiske dimension i undervisning - Om et grundtema hos Emmanuel Lévinas» tar Jonas Holst utgangspunkt i to tilsynelatende motstridende forståelser av undervisningens karakter og oppgave. Disse bygger på ulike forståelser av etikkens natur - henholdsvis den sokratiske jordmorskunsten, der lærerens oppgave er å bringe fram den kunnskapen hun vet eleven besitter, og Lévinas' annethetsetikk, der undervisningen i likhet med ethvert genuint møte åpner for det som er radikalt annerledes, og derfor ikke lar seg innskrive i våre kjente kategorier. Holst argumenterer for en dialogisk mellomvei der læreren tar hensyn til elevens ressurser som utgangspunkt for en utvidelse av disse ressursene. Den paradigmatiske formen for en slik veiledende åpenhet er den muntlige samtalen, ansikt til ansikt.

I den siste artikkelen vendes blikket fra profesjonsetikk mot den etiskpolitiske betydningen av anerkjennelse. Odin Lysaker tar utgangspunkt i de siste tiårs rettighetskamper for utmynting av en normativ begrunnelse for menneskeverdet. Siden det som kan kalles et anerkjennelsesunderskudd utgjør en av de avgjørende utløsende faktorene for minoriteters kamp for sine rettigheter, er det nærliggende å anta at en diskusjon om anerkjennelse utgjør et godt utgangspunkt for avklaring av menneskets verdi. Lysakers artikkel, "Anerkjennelse og menneskeverdets forankring. Henimot en transnasjonal anerkjennelsespolitikk», sammenligner Jürgen Habermas' «tynne» og Axel Honneths «tykke» utlegninger av anerkjennelsesbegrepet. 
Her foreslås at disse posisjonene suppleres med en eksistensiell og subjektiv dimensjon som tar utgangspunkt i vår kroppslige sårbarhet som en felles og ufravikelig grunnforutsetning for anerkjennelse av menneskeverd. 